\title{
EL PROYECTO “CAMPAÑA EDUCATIVA PARA INCREMENTAR EL CONSUMO DE FRIJOLES"1
}

\author{
PROJECT: "EDUCATIONAL CAMPAIGN TO \\ INCREASE BEAN CONSUMPTION"1
}

\author{
Ligia Rodríguez ${ }^{2}$
}

\begin{abstract}
RESUMEN
El proyecto "Campaña educativa para incrementar el consumo de frijoles". Se describen las diferentes etapas que se siguen en el desarrollo de un proyecto denominado "Campaña educativa para incrementar el consumo de frijoles". La Campaña tuvo como objetivo "incrementar el consumo de frijoles en la población urbana de clase media de Costa Rica" y contribuir a contrarrestar la disminución en el consumo de este alimento, que se ha presentado en forma muy marcada en el área urbana. El artículo pretende ofrecer una visión global del mencionado proyecto, de manera que le permita al lector la ubicación dentro del proceso, al mismo tiempo que lo refiere a los artículos específicos que ofrecen el detalle de las diferentes etapas y resultados. La metodología describe las características generales del abordaje que se utiliza y la forma en que se desarrolla cada una de las etapas. Los resultados sumarizan los hallazgos de la evaluación y otros aspectos globales del proyecto. Además, ofrece pautas para un abordaje de la educación nutricional focalizada alrededor de un alimento y sustentada en la realidad social y cultural de la población.
\end{abstract}

Palabras claves: educación nutricional; frijoles; campaña; grupo objetivo.

\begin{abstract}
Project: "Educational Campaign to increase bean consumption". The different stages in the development of a project entitled "Educational Campaign to increase bean consumption" are presented in this article. The Campaign's objective was to "Increase bean consumption in the Costa Rican middle-class urban population", and to help counterbalance an increasing reduction in consumption of this food, particularly in urban areas. The article intends to provide an overall view of the project, allowing readers to gain perspective of the project as a whole, while also referring them to specific articles with the details on the different stages and results. The methodology describes the general characteristics of the approach used, and the way each one of the phases was carried out. The results summarize the findings of the final evaluation and other global aspects of the project. In addition, the project provides guidelines for an approach to nutritional education focused on one single food, supported by the population's sociocultural reality.
\end{abstract}

Key words: nutritional education, beans, campaign, target group.

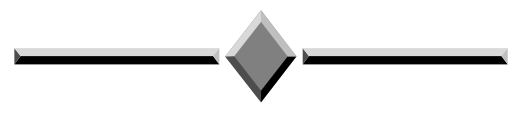

1 Recibido para publicación el 30 de junio del 2004. Este artículo se deriva de la investigación desarrollada en el Proyecto "Campaña Educativa para Incrementar el Consumo de Frijoles”, de la Escuela de Nutrición de la Universidad de Costa Rica (UCR), inscrito dentro del proyecto macro "Mejoramiento de la Digestibilidad del Frijol", CITA-UCR, bajo el auspicio del Programa Bean/Cowpea CRSP; USAID Grant DAN-G-SS-86-0008-88.

2 Escuela de Nutrición, Universidad de Costa Rica. Investigadora principal del "Proyecto Campaña Educativa para Incrementar el Consumo de Frijoles". E-mail: farodri@racsa.co.cr
1 Received for publication on June 30, 2004. This article is the result from the investigation carried out as part of the Project "Educational Campaign to Increase Bean Consumption" , from the University of Costa Rica's Nutrition School, which is part of the macro-project "Improving Digestibility of Beans", CITA, UCR, sponsored by the Bean/Cowpea CRSP Program; USAID Grant DAN-G-SS-86-0008-88.

2 University of Costa Rica, School of Nutrition. Principal Researcher Project "Educational Campaign to Increase Bean Consumption". 


\section{INTRODUCCIÓN}

El presente artículo ofrece una visión global del proceso desarrollado para realizar una Campaña educativa, orientada a mejorar la alimentación y nutrición en Sabanilla de Montes de Oca, una comunidad urbana de Costa Rica; mediante la promoción del consumo de un alimento específico: los frijoles.

La Campaña tuvo como objetivo "incrementar el consumo de frijoles en una población urbana de clase media de Costa Rica". Esto debido a que los frijoles, a pesar de ser consumidos por el $96,7 \%$ de la población del país (Ministerio de Salud 1996), han mostrado un descenso en la cantidad que se consume, particularmente en la zona urbana. Así, de un consumo promedio de frijoles de 57,0/gramos/persona/día $(\mathrm{g} / \mathrm{p} / \mathrm{d})$ en 1966 (INCAP/ICNND/Ministerio de Salubridad Pública de Costa Rica 1969), se pasó a 31,1 g/p/día, según la Encuesta de 1996. Para el área urbana, la situación es aún más crítica, con un consumo de 28,1 g/p/día (Ministerio de Salud 1996).

Los datos son preocupantes, tanto por el valioso aporte nutricional de los frijoles (US Department of Agriculture 2000) como por sus características funcionales (Sedó 2001, Sedó 2002), ya que este alimento contribuye de manera importante en la prevención y tratamiento de muchos de los principales problemas de salud que presenta el perfil epidemiológico del país (Sáenz 1995). En el artículo "Los frijoles, su aporte a la dieta del costarricense" (Rodríguez y Fernández 2003), se describe esa contribución.

El proceso que se siguió para desarrollar la Campaña, se documentó en una serie de artículos específicos, que permitirán al lector profundizar en diferentes aspectos de la metodología utilizada y conocer los resultados obtenidos.

Es necesario aclarar que este artículo no hace referencia a un estudio sino a un proceso. Consecuentemente, el contenido de la metodología y de los resultados difiere de lo que tradicionalmente se presenta en estos espacios. Por el contrario, ofrece una visión de conjunto y constituye un marco de referencia para el lector interesado en la globalidad del proceso.

Es necesario resaltar que el objetivo mismo de la Campaña "incrementar el consumo de frijoles"; condicionó un abordaje particular, ya que la educación nutricional se circunscribió, a un único alimento. Tal situación difiere de otros abordajes que se abocan a "mejorar la dieta", por medio de esquemas tales como "los grupos básicos de la alimentación", "la pirámide

\section{INTRODUCTION}

This article presents a comprehensive outlook of the process of implementing an educational Campaign aimed at improving the nutritional condition of people in Sabanilla de Montes de Oca, a Costa Rican urban community. This will be achieved by promoting consumption of a specific food: beans.

The Campaign's objective was "to increase bean consumption in a Costa Rican middle class urban population". It was based on the fact that even if beans are consumed by $96.7 \%$ of the country's population (Ministerio de Salud 1996), a reduction has been observed in the amount eaten, particularly in urban areas. That is, it went from an average bean consumption of 57.0 grams per person per day $(\mathrm{g} / \mathrm{p} /$ day $)$ in 1966 (INCAP/ICNND/ Ministerio de Salubridad Pública de Costa Rica 1969), to $31.1 \mathrm{~g} / \mathrm{p} /$ day in 1996 , according to the nutrition survey of that year. For urban areas the situation is even more critical, with a consumption of $28.1 \mathrm{~g} / \mathrm{p} /$ day (Ministerio de Salud 1996).

This information is disturbing not only because of the nutritional value of beans (US Department of Agriculture, 2002), but also because of their functional qualities (Sedó 2001 and 2002), for which they play an important role in the prevention and treatment of many of the main health problems observed in the country's epidemiological profile (Sáenz 1995). A description of this contribution is presented in the article entitled "Beans (Phaseolus vulgaris): their contribution to the diet of Costa Ricans" (Rodríguez and Fernández 2003).

The Campaign implementation process was documented with a series of specific articles, which will allow readers to get a deeper understanding of the different aspects of the methodology used, and information on the results obtained.

This article does not refer to one particular study, but to the process as a whole. Consequently, the contents under the headings of Methodology and Results are different from the information that is usually presented in those sections. On the contrary, the article provides an overall perspective and it is a reference framework for readers interested in the process as a whole.

The very objective of the Campaign, i.e., "to increase bean consumption", called for a particular approach, because nutritional education was limited to one single food. Other strategies aimed at improving the diet, follow more general schemes such as "basic food groups", "the nutritional pyramid", and 
nutricional" y "las guías alimentarias" (Sizer y Whitney 1997, Earl y Borra 2000, Ministerio de Salud de Costa Rica 2001). Sedó, se refiere a diferentes alternativas de agrupaciones de alimentos y cuestiona el hecho de que este tipo de orientación no le deja claro al consumidor las cualidades de los productos alimenticios (Sedó 2002).

El abordaje educativo de la Campaña, presentó características innovadoras con respecto a otras metodologías de educación nutricional utilizadas y podría ofrecer aportes valiosos a las personas y grupos interesados en esta temática.

\section{METODOLOGÍA}

\section{A. Población}

El proyecto se desarrolló en Sabanilla de Montes de Oca. Esta es una comunidad urbana situada a $6 \mathrm{~km}$ de San José, capital de Costa Rica, que tiene una alta proporción de familias de clase media. Además, presenta muchas de las características propias de comunidades urbanas del país: buena organización comunal que se refleja en la existencia de varios grupos organizados; infraestructura típica (una iglesia principal, un parque y un centro educativo que constituyen el centro de la comunidad) y comercio de alimentos que se ofrece a través de: supermercados, pulperías, sodas y una feria de productos agroalimentarios un día a la semana. Existen, además, varios centros educativos públicos y privados y servicios de salud (Campos et al. 1999).

La población objetivo que se definió para la Campaña la constituyeron las "madres de escolares, de clase media urbana". Esto contribuyó a focalizar aún más el proceso y permitió la identificación de un grupo interactivo y de un grupo de apoyo.

Los grupos interactivos deben caracterizarse por mantener un estrecho contacto con el grupo objetivo, de manera que puedan reforzar en éste los mensajes que se le envían. En este caso, los escolares de tercero y cuarto grados (de 9 a 11 años de edad) se consideraron, como un grupo interactivo idóneo, ya que aún mantienen una relación cercana con sus madres y tienen un nivel de captación y objetividad apropiados.

Los "grupos de apoyo" deben estar constituidos por personas que pueden influir en la formación de opinión del "grupo objetivo". En este caso, se consideró como "grupo de apoyo" el personal local de salud, el personal de las escuelas y de los comedores y sodas escolares y algunos líderes de la comunidad. Estas personas fueron informadas y educadas sobre el tema, "alimentary guidelines" (Sizer and Whitney, 1997; Earl and Borra, 2000; Ministerio de Salud de Costa Rica, 2001). Sedó refers to different ways to classify foods, and questions the fact that this type of approach does not provide consumers with a clear idea about the qualities of alimentary products (Sedó, 2002).

The Campaign's educational strategy presented innovative characteristics as compared to other educational nutrition methodologies used, and it might offer valuable contributions to people and groups interested on this subject.

\section{METHODOLOGY}

\section{A. Population}

The Project was carried out in Sabanilla de Montes de Oca, an urban community located 6 kilometers away from San José, the capital city of Costa Rica. This community has a high proportion of middle-class families and presents many of the characteristics of urban communities in the country: it is well organized, having several organized groups, standard infrastructure (main church, a park, and an educational center that constitute the center of the community), and food traded through supermarkets, small grocery stores or 'pulperías', food stands, and a farmers market that takes place once a week. There are also several public and private educational centers, and health care facilities (Campos et al. 1999).

The target population defined for the Campaign were "the middle-class mothers of school children". This helped focalize the process even more, and allowed defining the adequate interactive and support groups.

A characteristic of "interactive groups" is that they have to keep close communication with members of the target group, so that they can reinforce the messages sent to them. In this case, third- and fourth-grade school children (between 9 and 11 years old) were considered as an ideal interactive group, given that they have a close relationship with their mothers and a good level of understanding and objectivity.

"Support groups" must be made up by people that may influence opinion making within the "target group". In this case, local health care personnel, teaching staff and personnel from school lunch rooms and food stands, and some community leaders were chosen to act as the support group. These people received information and training on the subject, so that they could reinforce the messages sent to the target 
para que contribuyeran a reforzar los mensajes y evitar contradicción entre los que emitía la "Campaña" y sus propias recomendaciones. Alcalay (1983), se refiere a este fenómeno como monopolización "cuando comunicaciones contrarias no alcanzan a la audiencia".

\section{B. Proceso}

Se utilizó un modelo de participación comunitaria, tendiente a lograr modificaciones en la población, en el mismo lugar en donde viven. Por lo tanto, todo el proceso se desarrolló en forma interactiva con la comunidad, utilizando como eje la metodología cualitativa (Rodríguez y Dumani 2000 a). El abordaje, incorporó muchas de las recomendaciones del modelo de comunicación de McGuire (citado por Pardío y Plazas 1998), que tiene como objetivo el desarrollo de estrategias de comunicación efectivas, que parten de la identificación del grupo objetivo, determinan su situación y utilizan diversos canales de comunicación para trasmitir mensajes comprensibles.

La Campaña se desarrolló en cinco etapas: 1 . Diagnóstico, 2. Definición de mensajes, 3. Planificación, 4. Ejecución y 5. Evaluación. En el Esquema 1 se presenta un flujograma de estas etapas y sus componentes más relevantes.

Las etapas 1 y 2 se desarrollaron por medio de dos trabajos finales de graduación: "Diagnóstico para el diseño de una Campaña Educativa para Aumentar el Consumo de Frijoles en una Comunidad Urbana de Clase Media" (Campos et al. 1999), y Elaboración de los contenidos de mensajes de una Campaña educativa para aumentar el consumo de frijoles en una comunidad urbana de clase media" (Martínez et al. 2000). Estos estudios involucraron a siete estudiantes de nutrición y a dos estudiantes de Ciencias de la Comunicación Colectiva de la Universidad de Costa Rica, bajo la asesoría de miembros del equipo de trabajo del proyecto.

El equipo de trabajo a cargo del proyecto fue multidisciplinario e involucró a tres nutricionistas, una comunicadora social y una psicóloga; quienes participaron a tiempo parcial. Esto último, aunque fue una limitante para el proyecto, fue subsanado por el compromiso del equipo, la participación activa de los estudiantes y porque el proyecto era de mediano plazo (se desarrolló en un período de alrededor de tres años).

A continuación se hace una breve descripción de cada una de las etapas. group, and avoid contradictions between messages from the Campaign and their own recommendations. Alcalay (1983), refers to this phenomenon as monopolization, "when opposite communications do not reach the audience".

\section{B. Process}

A model involving community participation aimed at achieving behavior modification in people at their place of residence was used. Therefore, the work was carried out through interactions with the community, mainly using a qualitative methodology (Rodríguez and Dumani 2000 a). This approach incorporated many of the recommendations from McGuire's communication model (quoted by Pardío and Plazas, 1998), whose objective is to create effective communication strategies by identifying the target group, defining its socio-cultural features, and using various communication channels to deliver understandable messages.

The Campaign was carried out in five phases: 1 . Initial assessment; 2. Message definition; 3. Planning; 4. Implementation, and 5. Final evaluation. A flowchart of these phases and their most relevant elements is presented in Diagram 1.

Two final graduation papers dealt with phases 1 and 2 of the Project. One was entitled "Diagnóstico para el diseño de una Campaña educativa para aumentar el consumo de frijoles en una comunidad urbana de clase media" ("Initial assessment to design an educational campaign to increase bean consumption in a middle-class urban community") (Campos et al. 1999), and the other one was entitled "Elaboración de los contenidos de mensajes de una Campaña educativa para aumentar el consumo de frijoles en una comunidad urbana de clase media" ("Content design for messages in an educational campaign to increase bean consumption in a middle-class urban community") (Martínez et al. 2000). Seven nutrition students and two mass communication students from the University of Costa Rica, advised by members from the Project's work team participated in these studies.

The work team in charge of the Project was made up by an interdisciplinary group of professionals including 3 nutritionists, one social communicator, and a psychologist, who worked part time for the Project. Although part-time participation was a constraint, it was 


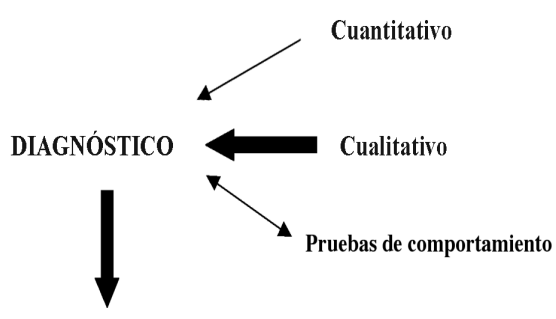

DEFINICIÓN DE MENSA.IES $\longrightarrow$ Plan de comunicación

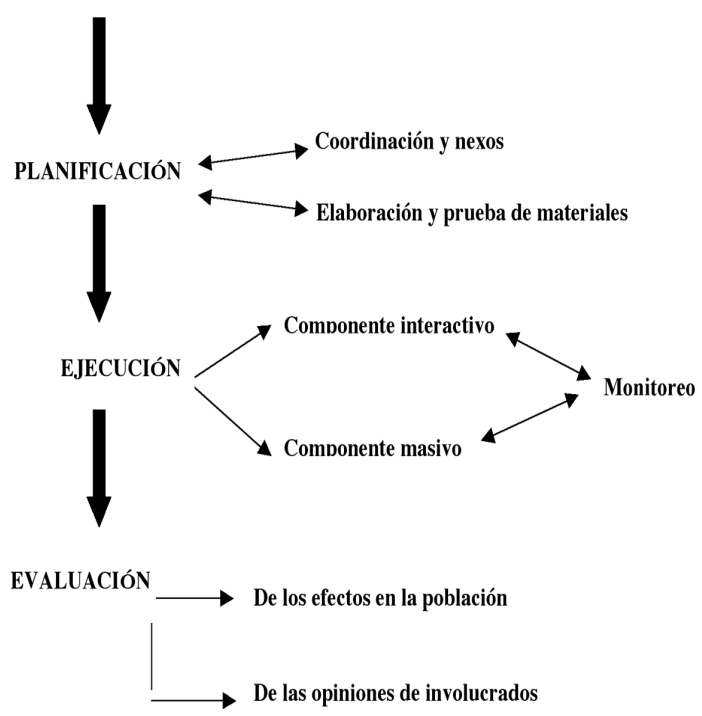

Esquema 1. Proceso de una Campaña Educativa para incrementar el consumo de frijoles. Sabanilla de Montes de Oca. Costa Rica, 1998-2001.

\section{Diagnóstico}

Esta etapa tuvo como eje la metodología cualitativa, pero se complementó con datos cuantitativos y "pruebas de comportamiento". El diagnóstico, como base para cualquier intervención educativa que tienda a modificar hábitos alimentarios, constituye una necesidad que ha sido señalada por numerosos autores. Adrien (1994), plantea que "es crucial entender por qué la gente actúa de la forma en que lo hace. En general, la gente tiene razones válidas para ello. Por lo tanto, es importante descubrir cuáles son esas razones, antes de tratar de introducir cualquier modificación a sus hábitos". Chinnock y De Beausette (1996) indican que "el proceso de enseñanza aprendizaje debe basarse en la realidad de los educandos, de manera que se logre una síntesis de los dos saberes: el científico y el cultural".

El diagnóstico incluyó un estudio cuantitativo sobre el consumo de frijoles en familias de clase media con escolares de la comunidad seleccionada y dos estudios cualitativos sobre los conocimientos, actitudes y
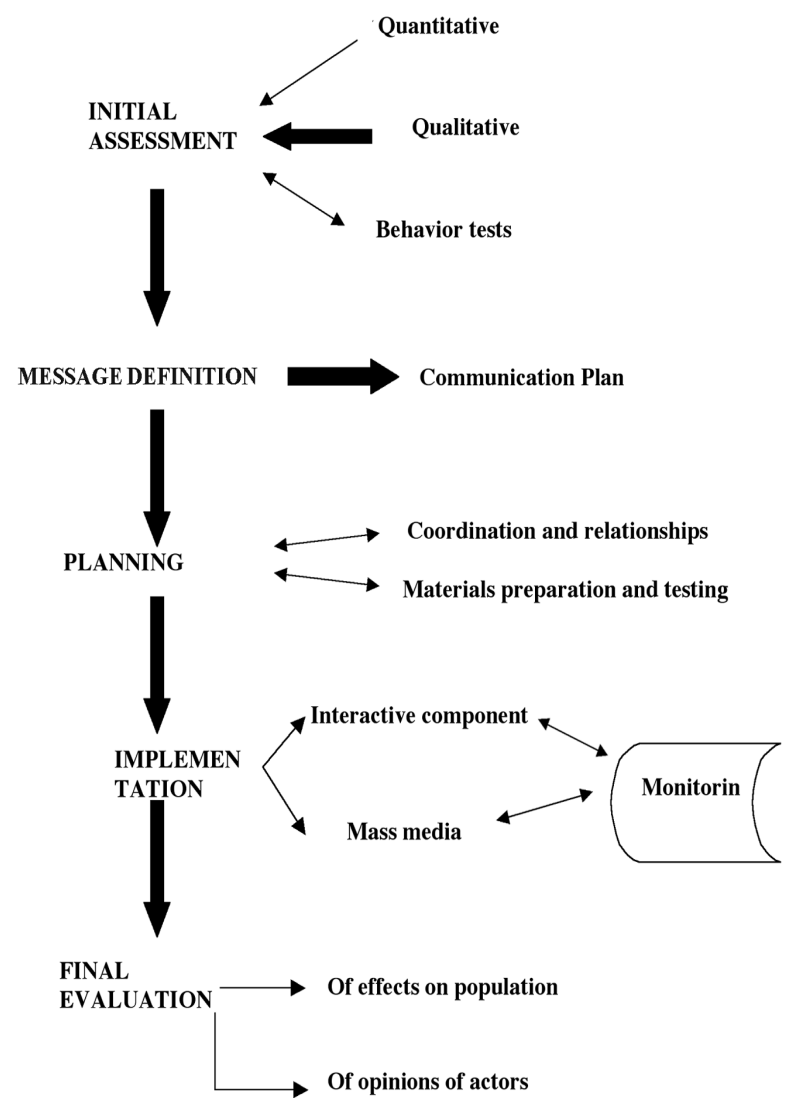

Diagram 1. Process for an Educational Campaign to Increase Bean Consumption Sabanilla de Montes de Oca, Costa Rica, 1998-2001.

counterbalanced by the team's commitment, the students' active participation, and because it was a medium-term Project that was carried out in three years.

A brief description of each one of the phases is presented below.

\section{Initial assessment}

This phase was based on a qualitative methodology, complemented with quantitative data and "behavior tests". As pointed out by many authors, the initial assessment must be the basis for any educational action aimed at modifying eating habits. Adrien (1994) states that "it is critical to understand why people act the way they do. In general, people have valid reasons for their actions. Therefore, it is important to find out about their reasons, before trying to introduce changes in their habits". Chinnock and De Beausette (1996), indicate that "the teaching-learning process must be based on the reality of pupils, so as to be able to 
prácticas con respecto a los frijoles (Rodríguez y Dumani 2000 b). Uno con la población objetivo (madres de escolares) y otro con el grupo interactivo (escolares). Además, con estos últimos se evaluaron las actitudes con respecto a los frijoles. Los datos para estos estudios se obtuvieron en 1998.

El diagnóstico incluyó también un estudio observacional sobre la comunidad, sus grupos organizados y recursos. Se obtuvo información sobre canales y medios de comunicación que utilizaba la población objetivo, incluyendo la identificación de los programas de radio y televisión con mayor audiencia, la prensa escrita más leída y otros medios que las madres indicaban como convenientes para recibir información. Asimismo, se indagó sobre gustos y preferencias con respecto a colores y formas en anuncios y material impreso (Campos et al. 1999).

Seis meses después de realizar la primera encuesta diagnóstica, en el primer semestre de 1999, se llevó a cabo un estudio complementario, en una submuestra de la misma población (Rodríguez y Rodríguez 2003), con el objetivo de rescatar otra información necesaria: completar los datos con el consumo de frijoles molidos enlatados y determinar los lugares en los que la población recibía atención de salud.

También en 1999 se llevaron a cabo pruebas de comportamiento (Sáenz 1995) con respecto a los frijoles, según fue descrito por Martínez et al. 2000 y Dumani y Rodríguez 2004. Mediante estas pruebas se obtuvieron las "prácticas factibles", es decir, aquellas que tenían posibilidad de ser adoptadas. Esta información complementó el diagnóstico.

\section{Definición de mensajes}

Con la información obtenida en el diagnóstico y en el estudio sobre "prácticas factibles", se identificaron: barreras que limitaban el consumo de frijoles, conocimientos y prácticas erróneas o inexistentes y actitudes negativas que sería necesario contrarrestar. También se rescataron las prácticas y los conocimientos adecuados, así como las actitudes positivas que la población manifestó y que era importante reforzar. Todo esto constituyó un mosaico de alternativas, que sirvió de base para elaborar los mensajes (Martínez et al. 2000).

Con este marco de referencia, se definieron las ideas centrales de los mensajes. Estas se formularon como contenidos de los mensajes, procurando la mayor claridad posible y utilizando el lenguaje popular con respecto a los frijoles. achieve a synthesis of their scientific and cultural knowledge".

The initial assessment included a quantitative study on bean consumption by middle-class families with school children from the selected community, as well as two qualitative studies on knowledge, attitudes, and practices with regards to beans. One with the target group (mothers of school children), and the other with the interactive group (school children). Attitudes with regards to beans were also assessed in the group of children. Data for these studies were gathered during 1998.

The initial assessment also included an observation study about the community, its organized groups and resources. Information was gathered about communication channels used by the target population, including an identification of top-audience radio and television programs, most popular newspapers, and other means that mothers had indicated as convenient to receive information. People's preferences with regards to colors and shapes in advertisings and printed material (Campos et al. 1999) were also identified.

Six months after the first survey for the initial assessment was carried out (during the first semester of 1999) a complementary study was implemented in a sub-sample from the same population (Rodríguez and Rodríguez, 2003). The purpose of this study was to obtain other information required, like consumption of mashed canned beans and the health care facilities used by the population.

Also, during 1999 behavior tests (Sáenz 1995) were conducted with regards to beans, as described by Martínez et al. (2000), and Dumani and Rodríguez (2004). The results of these tests were used to draw up the "feasible practices", i.e., those that had a good chance of being adopted by people. This information complemented the initial assessment.

\section{Message definition}

The barriers to bean consumption, inadequate knowledge or practices - or the lack of them - and negative attitudes that would be convenient to change, were identified based on the information from the initial assessment, and from the study on "feasible practices"; adequate practices, knowledge, and positive attitudes were also identified. All this information provided a range of alternatives that were the basis to write the messages (Martínez et al. 2000). 
En este caso, una ventaja fue el hecho de que los frijoles son un alimento de uso común y existe una cultura alrededor de su utilización, la cual se rescató en el diagnóstico. Ello permitió que en la Campaña, se pudieran reforzar valores y prácticas preexistentes. Alcalay (1983) y Gillespei y Yarbrough (1984), indican que las audiencias internalizan con mayor facilidad aquellos mensajes que son consistentes con sus propios valores, actitudes y prácticas.

Con el objeto de validar los contenidos de los mensajes, estos fueron probados con las diferentes audiencias: madres de escolares, escolares y líderes comunales.

Como resultado se obtuvieron los mensajes a emitir, los cuales se integraron al plan de comunicación, que se utilizó en la planificación y evaluación de la Campaña (Páez y Rodríguez 2004).

\section{Planificación de la Campaña}

La planificación se fundamentó en el plan de comunicación (Martínez et al. 2000; Páez y Rodríguez 2004) previamente elaborado, utilizando información del diagnóstico. Un artículo específico (Rodríguez y Rodríguez 2004) describe el proceso metodológico seguido durante la etapa de planificación.

Como resultado de ese proceso se obtuvo el documento "Plan de la Campaña", con planes de trabajo específicos para la comunidad, las escuelas y uno de los grupos de apoyo (solamente se detalló para el personal de salud); así como el plan de comunicación masiva e incidencia en medios. La utilización de diversos medios y canales es una recomendación de diversos autores (Adrien 1994, Pardío y Plazas 1998, Navarro 1998).

También se elaboró un cronograma de trabajo que desglosaba las actividades en tareas específicas y asignaba el (los) responsable(s), y el período en que se desarrollaría cada tarea. Ambos instrumentos constituyeron el marco de referencia para la etapa de ejecución de la Campaña.

El plan de Campaña tuvo como objetivo general "Incrementar el consumo de frijoles" y como objetivos específicos: a) Informar sobre los beneficios del consumo de los frijoles; b) Formar a la población sobre las técnicas más adecuadas de preparar, conservar y consumir frijoles y c) Neutralizar las barreras que interferían con el consumo.

La planificación implicó una ardua labor de coordinación, tanto con la comunidad, como con otras
The "main ideas for messages" were drawn out from this reference framework. These ideas were written as message contents, trying to be as clear as possible and using popular language.

The fact that beans are commonly used and there is a cultural tradition about their handling and consumption - which was identified during the initial assessment - turned out to be a good advantage in this case. This was used during the Campaign to reinforce existing positive values and practices. Alcalay (1983) and Gillespei and Yarbrough (1984), indicate that it is easier for audiences to incorporate messages that are consistent with their own values, attitudes, and practices.

In order to validate message contents, they were tested with the different audiences: mothers of school children, school children and community leaders.

As a result, the messages to be delivered were drawn up and integrated into the communication plan, which was used for planning and evaluating the Campaign (Páez and Rodríguez 2004).

\section{Campaign planning}

Planning was based on the matrix for the communication plan (Martínez et al. 2000; Páez and Rodríguez 2004) previously designed, using information from the initial assessment. There is a specific article (Rodríguez and Rodríguez 2004) describing the methodological process followed during the planning phase.

A document entitled "Campaign Plan" was derived from this process, with specific work plans for the community, the schools, and one of the support groups (the health care staff), as well as the mass communication plan. Use of various means and communication channels is recommended by several authors (Adrien 1994, Pardío and Plazas 1998, Navarro 1998).

A work chronogram was also drawn up to indicate specific tasks and designate the groups in charge, and the time period for each task. Both instruments were used as a reference framework for the Campaign's implementation phase.

The general objective of the Campaign plan was to "Increase bean consumption", and the specific objectives were: a) inform on the benefits of bean consumption, b) instruct the population about the most 
instituciones, grupos y personas externas al proyecto. La mayor parte de los nexos se establecieron desde la etapa de Planificación y continuaron durante las etapas de ejecución y de evaluación.

En la comunidad se coordinó con las directoras y los docentes de los centros educativos seleccionados: José Figueres Ferrer, Educativo Campestre y Monterrey y se organizaron reuniones con grupos organizados de la comunidad. Las relaciones con las empresas locales de venta de alimentos se establecieron por medio de entrevistas con los gerentes o dueños de cada local comercial.

Paralelamente hubo un trabajo intensivo de elaboración y prueba de materiales. Para esta Campaña, se elaboraron los siguientes materiales: un recetario $(\mathrm{Du}-$ mani y Rodríguez 2000), dos panfletos, afiches con mensajes alusivos y un folleto para personal de salud. También se diseñaron 12 cuñas radiales, con los mensajes más relevantes de la Campaña.

Siguiendo la recomendación de Adrien (1994) de probar los materiales antes de proceder a reproducirlos masivamente, los de esta Campaña fueron validados con grupos de población similares a la audiencia meta (grupos objetivo e interactivo y personal de salud). Las observaciones que surgieron de estas pruebas se utilizaron para hacer los ajustes necesarios antes del tiraje definitivo del material.

Para conseguir apoyo complementario se estableció coordinación con la empresa privada. La Empresa Pedro Oller brindó su colaboración, en el marco de una "carta de entendimiento" entre esta Empresa y la Universidad de Costa Rica. Otras instituciones con las que se establecieron nexos fueron: la Caja Costarricense del Seguro Social (CCSS); el Instituto Nacional de Aprendizaje (INA); la Oficina de Divulgación de la Universidad de Costa Rica (ODI) y los medios de comunicación masiva (radio, prensa y televisión). En esta forma la planificación cumplió con la recomendación de Morón y Calderón (1999), sobre la necesidad de incorporar, en el proceso de la educación nutricional, no solo a los sectores de salud y educación, sino a la industria de alimentos, el comercio, los medios de comunicación de masas $\mathrm{y}$ otros actores sociales; ya que tienen gran influencia sobre las conductas alimentarias de la población.

\section{Ejecución de la Campaña}

Esta etapa contempló actividades interactivas y de comunicación masiva planificadas para ejecutarse en forma intensiva en un período de tres meses. Sin embargo, por atrasos con el programa radial fue necesario adequate techniques to prepare, preserve, and consume beans, and c) eliminate barriers to bean consumption.

Planning entailed a great coordination effort with the community, and other institutions, groups and persons from outside the Project. Most of the relationships were established starting from the planning phase, and were maintained during the implementation and evaluation phases.

In the community, activities were coordinated with principals and teaching staff from the selected schools, and meetings were held with organized groups from the community. Relationships with local food stores were established through interviews with managers or owners of each facility.

In parallel, an intense effort was made to prepare and test the materials for the Campaign: a recipe book (Dumani and Rodríguez 2000), two brochures, posters with suggestive messages, and a brochure specifically designed for health care personnel. Twelve radio spots were also made with the most important messages of the Campaign.

Following Adrien's recommendation (1994) to test all materials before requesting their massive reproduction, the ones for this Campaign were validated with population groups similar to those of the different audiences (target and interactive groups, and health care staff). Observations derived from these tests were used to make the necessary changes before the materials were reproduced.

Coordination with private businesses was necessary in order to obtain complementary support. The Pedro Oller company contributed by means of a "letter of understanding" between this company and the University of Costa Rica. Other institutions with which partnerships were established were the CCSS (the Costa Rican Social Security System), INA (the National Learning Institute), ODI (the University of Costa Rica's Divulgation Office) and the mass media (radio, newspapers and television). In this way, planning met the recommendation from Morón and Calderón (1999), about the need to integrate nutritional education not only to health and education sectors, but also to sectors such as the food industry, commerce, mass media, and other social actors, due to their significant influence on people's alimentary habits.

\section{Campaign implementation}

According to the plan, this phase comprised interactive and mass communication efforts to be 
ampliarla por tres meses más. La Campaña se llevó a cabo de mediados de setiembre a mediados de diciembre del 2000. Se reinició en febrero del 2001y terminó en abril de ese mismo año ${ }^{3}$.

Las actividades interactivas que se realizaron fueron: una Feria del Frijol y la Salud, la ubicación de puestos promocionales en supermercados, diferentes actividades con los escolares (charlas, preparación de recetas, elaboración de carteles, taller de teatro), y charlas al personal de salud local y al personal de comedores y sodas escolares. En el diagnóstico se había detectado la dificultad de las madres para reunirse, por lo que no se planificaron ni ejecutaron actividades presenciales con el grupo objetivo (Rodríguez y Rodríguez 2004).

Las actividades de comunicación masiva se llevaron a cabo por medio de afiches que se colocaron en lugares públicos muy frecuentados (paradas de buses, supermercados, iglesia, pulperías y farmacia); panfletos y recetarios que se enviaron a las madres por medio de los escolares y los medios de comunicación masiva (radio, prensa y televisión).

Por el costo de los espacios de radio, prensa y televisión, solamente se habían elaborado 12 cuñas radiales a ser transmitidas con financiamiento de la CCSS, a través de diferentes medios. Sin embargo, la apertura que se logró en los medios de comunicación masiva fue muy amplia, lo que permitió una mayor difusión y una proyección que trascendió la comunidad de Sabanilla.

La etapa de ejecución contemplaba también el seguimiento del proceso o monitoreo. El monitoreo cumple diversas funciones tales como: evaluación formativa, introducción de ajustes al proceso y garantía de coherencia con los objetivos (Hurtado 19994, FAO 1994).

Durante la ejecución de la Campaña, se dio seguimiento al cumplimiento del plan y se monitorearon algunas de las actividades y de los materiales distribuidos. Algunos de los hallazgos fueron utilizados durante la etapa de ejecución, para hacer ajustes al plan o a la logística de trabajo. Otros resultados del monitoreo permitieron determinar el nivel de aceptación de los materiales utilizados y proporcionaron información sobre aspectos en los que la población tenía un interés

3 La suspensión de actividades de la Campaña entre diciembre 2000 y enero 2001 se debió a las festividades de navidad, de fin y principio de año y vacaciones de verano.

4 Hurtado, H. 1999. Evaluación cualitativa. Antropóloga e investigadora del Instituto de Nutrición de Centroamérica y Panamá (INCAP). Comunicación personal. implemented intensively during a three-month period. However, due to delays with the radio program, it was necessary to extend it for three more months. The Campaign was carried out between the middle of September and the middle of December, 2000. It started again in February 2001 and ended in April of the same year ${ }^{3}$.

The interactive activities implemented were a "Health and Bean Fair", promotional stands in supermarkets, different activities with school children (talks, recipe preparation, poster making, theater workshop), and conferences to local health care personnel, and to people in charge of school lunch rooms and food stands. The difficulty of mothers to attend meetings had been detected in the initial assessment; for this reason meetings were not planned or implemented with them (Rodríguez and Rodríguez 2004).

Mass communication activities were carried out through posters that were placed in much frequented public areas (bus stops, supermarkets, church, pulperías, and pharmacies), brochures and a recipe book that were sent to mothers with their school children, and use of the mass media (radio, newspapers and television).

Since radio, newspaper and television advertising was costly, only 12 radio spots were made to be broadcast with financing from the CCSS, through different means. However, mass media businesses were willing to contribute, which allowed greater coverage, reaching beyond the community of Sabanilla.

The implementation phase also included monitoring of the process. Monitoring fulfills several functions such as: follow-up evaluation, ongoing changes and assurance that there is consistency with the objectives (Hurtado 19994, FAO 1994).

Compliance with the plan, as well as some of the activities and materials handed out, were monitored during Campaign implementation. Some of the findings were used during the implementation phase to make changes in the plan or the logistics as the Campaign was being implemented. Other results from follow-up made it possible to determine the degree of

\footnotetext{
3 It was necessary to interrupt the activities of the Campaign between December 2000 and January 2001, due to the Holiday celebrations and summer vacation.

4 Hurtado, H. 1999. Qualitative evaluation. Anthropologist/ Researcher from INCAP (the Central America and Panama Nutrition Institute). Personal interview.
} 
particular. El artículo de Dumani y López (2004) documenta esos resultados.

\section{Evaluación}

La evaluación tenía como propósito determinar los efectos de la Campaña, en el mediano plazo, con respecto a los objetivos que se habían establecido en el plan. Los objetivos específicos de la evaluación fueron:

- Determinar el consumo de frijoles en el 2001 (a un año de iniciada la Campaña) y compararlo con el consumo de 1999;

- Determinar el cumplimiento de los objetivos de la Campaña con respecto a los conocimientos, actitudes y prácticas (CAP) de madres y niños;

- Identificar las fortalezas y debilidades del proceso, así como las lecciones aprendidas por el equipo de trabajo;

- Obtener la visión de la empresa que apoyó el proyecto sobre la Campaña y la coordinación establecida con la empresa para el desarrollo de la misma.

Para cumplir con esos objetivos, se realizaron tres estudios y dos entrevistas. Uno de los estudios fue sobre el consumo de frijoles después de la Campaña y los otros dos describieron los efectos de la Campaña sobre los conocimientos actitudes y prácticas de las madres y los niños (as) (Dumani y Páez 2004; Rodríguez 2004)

Las entrevistas se orientaron a obtener una visión del proyecto, desde la perspectiva de los involucrados directos: el equipo de trabajo a cargo del proyecto y la empresa que colaboró con la Campaña. Con la comunidad no se realizaron entrevistas grupales, pero se incorporaron preguntas de evaluación de la Campaña en el estudio que se llevó a cabo con las madres.

Con el equipo de trabajo se realizó una entrevista grupal estructurada y se llenó un cuestionario complementario. En esta entrevista participaron: el equipo de trabajo, algunos de los estudiantes que trabajaron en el proyecto y la coordinadora del "proyecto Macro"5. Con la empresa se llevó a cabo una entrevista individual no estructurada, de miembros del equipo de trabajo con $\mathrm{Sr}$. José Oller, representante de la Empresa Pedro Oller, quien fue el vínculo del proyecto con la empresa.

5 El proyecto "Campaña Educativa para incrementar el consumo de frijoles, formaba parte de un proyecto macro que abarcaba varios otros proyectos acceptance of the materials used, and provided information about aspects that were particularly interesting for the population. The article by Dumani and López (2004) documents these results.

\section{Evaluation}

The purpose of the evaluation phase was to determine the medium-term effects of the Campaign on the objectives that had been proposed in the plan. The specific objectives of the evaluation phase were:

- Determine bean consumption in the year 2001 (one year after the Campaign was launched), and compare that information with consumption in 1999;

- Determine compliance with the Campaign's objectives with regards to knowledge, attitudes, and practices (KAPs) of mothers and children;

- Identify strengths and weaknesses of the process, as well as the lessons learned by the work team;

- Get the opinion from the company that supported the Project, about the Campaign itself, and the coordination with the company.

In order to fulfill these objectives, three studies and two interviews were carried out. One of the studies was about bean consumption by families after the Campaign; and the other two described the effects of the Campaign on knowledge, attitudes and practices of mothers and children (Dumani and Páez 2004; Rodríguez 2004).

The interviews were conducted to obtain information about the participants' perspective on the Project, i. e., the work team in charge of the Project and the company that collaborated with the Campaign. Group interviews were not conducted with people in the community, but questions to assess the Campaign were asked in the study with mothers.

A structured group interview was carried out with the work team, and a complementary questionnaire was filled out. The work team, some of the students who worked in the Project, and the coordinator of the "Macro-Project5" participated in this interview. Some members of the work team held a non-structured individual interview with Mr. José Oller, the representative from the Pedro Oller company, who was the link between the Project and the company.

5 The Project "Educational Campaign to Increase Bean Consumption" was part of a macro-project that comprised several projects. 


\section{RESULTADOS}

Los resultados de cada una de las etapas están descritos en los correspondientes artículos e informes, por lo que en este trabajo solamente se presentan algunos resultados globales de la evaluación.

En el Cuadro 1 se citan los documentos que se generan en las distintas etapas del proceso.

Algunos de los efectos positivos de la Campaña, que fueron detectados durante la evaluación son:

- En las familias que corresponden al grupo objetivo, el consumo de frijoles se incrementó de 25,5 g/p/día en 1999 (Rodríguez y Rodríguez 2003), a 46,9 g/p/día en el 2001 (Rodríguez y Páez 2004). Esta diferencia es estadísticamente significativa y muestra un consumo de frijoles similar, en la comunidad urbana de este estudio, al del área rural de Costa Rica, en donde el consumo de este alimento se ha mantenido alto (Ministerio de Salud 1996).

- La frecuencia semanal y el número de veces por día que las madres consumían frijoles se incrementó después de la Campaña (Dumani y Páez 2004).

- La mayoría de las madres continuaban utilizando las prácticas recomendadas durante la Campaña. (Dumani y Páez 2004).

- El porcentaje de escolares que consumía frijoles pasó de $91 \%$ en 1998 a 94\% en el 2001 (Campos et al. 1999; Rodríguez 2004).

- El $100 \%$ de los escolares evaluados reconoció que los frijoles son beneficiosos para la salud. Las razones que dieron para ello fueron nutricionales y de prevención de enfermedades (Rodríguez 2004).

- De los escolares evaluados un $73 \%$ reconoció que después de la Campaña consumía más frijoles. Esto refleja un cambio de actitud importante, que es necesario para mantener cambios en el largo plazo.

Es necesario aclarar que, por razones presupuestarias, no se pudo contar con una comunidad control y por lo tanto, los resultados de los diferentes estudios desarrollados, solamente permiten evaluar los efectos de la Campaña pero no el impacto de la misma.

En general, la confrontación de los resultados con los diferentes "indicadores de éxito" establecidos en el plan de comunicación, demostraron resultados positi-

\section{RESULTS}

Results from each phase are described in the corresponding articles and reports. Therefore, only some general results from the evaluation are presented in this article.

Table 1 includes the documents that were generated in each one of the phases of the process.

Some of the positive effects of the Campaign that were detected during evaluation are:

A bean consumption increase in families belonging to the target group, which went from $25.5 \mathrm{~g} / \mathrm{p} /$ day in 1999 (Rodríguez and Rodríguez 2003 ), to $46.9 \mathrm{~g} / \mathrm{p} /$ day in 2001 (Rodríguez and Páez 2004). This is a statistically significant difference and shows that bean consumption in the urban community studied is similar to that of Costa Rican rural areas, where bean consumption has traditionally been high (Ministerio de Salud 1996).

- The number of times per day and per week that mothers consume beans increased after the Campaign (Dumani and Páez 2004).

- Most mothers continued to apply the practices recommended during the Campaign (Dumani and Páez 2004).

- The percentage of school children that consumed beans went from $91 \%$ in 1998, to $94 \%$ in 2001 . (Campos et al. 1999; Rodríguez 2004).

- One hundred per cent of the school children in the study acknowledged that beans are healthful. The answers they gave were related to nutritional and disease prevention aspects (Rodríguez 2004).

- Out of the total number of school children assessed, $73 \%$ acknowledged that they consumed more beans after the Campaign (Rodríguez 2004). This shows an important attitude change, which is necessary to maintain the changes in the long term.

Due to limitations in its budget, the Project did not have a control community. Therefore, the different studies carried out could only assess effects of the Campaign, but not its full impact.

In general, a comparison of the results with the different "success indicators" established in the communication plan, shows positive results. The 
Cuadro 1. Etapas del proceso y publicaciones. Campaña Educativa para Incrementar el Consumo de frijoles. Sabanilla de Montes de Oca, Costa Rica 1999-2004

Etapas del proceso Publicaciones

1) Diagnóstico Campos E, Fernández A, Sánchez I, Sancho T.; Villalobos C. 1999. Diagnóstico para el diseño de una Campaña educativa tendiente a incrementar el consumo de frijoles en una comunidad urbana de clase media de Costa Rica. Seminario de Licenciatura. San José, Costa Rica: Universidad de Costa Rica.. 153 p.

Rodríguez, L.; Dumani, M. 2000 a. Diagnóstico para una Campaña educativa para la promoción del consumo de frijoles. In: Libro de Resúmenes de Trabajos Libres del XII Congreso Latinoamericano de Nutrición; SLAN 2000. Buenos Aires, Argentina: Secretaría Científica CESNI.

Rodríguez, L; Dumani M. 2000 b. Campaña educativa con respecto al consumo de frijoles. In: Memorias del IV Taller Anual de Resultados de Investigación y Transferencia de Tecnología PITTA-Frijol. Ed. por Revista Agronomía Mesoamericana. San José, Costa Rica: Profrijol.

Rodríguez, L; Rodríguez, S. 2003. Consumo de frijoles y atención en salud de familias de una comunidad urbana de Costa Rica .Revista Costarricense de Salud Pública. Año 12, No. 23: 47-51.

Murillo, A.; Rodríguez, S. 2004 a. Conocimientos, actitudes y prácticas de madres de escolares con respecto a frijoles. Agronomía Mesoamericana 15(3): 277-289.

Murillo , A.; Rodríguez, S. 2004 b. Frijoles: prácticas factibles de aplicar por madres de niños escolares urbanos. Agronomía Mesoamericana 15(3): 301-313.

Dumani, M.; Rodríguez, S. 2004. Proceso de determinación de prácticas nutricionales recomendables con respecto a los frijoles. Revista Costarricense de Salud Pública. Año 13 No. 24: 32-38.

Rodríguez, S; Murillo, A. 2004. Conocimientos, actitudes y prácticas de escolares con respecto a frijoles. Agronomía Mesoamericana 15(3): 291-300.

2) Definición de Martínez, T; Murillo, A; Rodríguez, S.; Páez, P. 2000. Elaboración de los contenidos de los mensajes de una CamMensajes paña Educativa para aumentar el consumo de frijoles en una comunidad urbana de clase media. Seminario de Licenciatura. San José, Costa Rica: Universidad de Costa Rica.. 103 p.

Páez y Rodríguez 2004. Plan de comunicación: un buen instrumento para que su campaña tenga éxito. Agronomía Mesoamericana 15(3): 315-326.

3) Planificación y Rodríguez, L.; Rodríguez, S. 2000. Informe 2000 del proyecto "Campaña educativa para incrementar el consumo 4)ejecución de la de frijoles". San José, Costa Rica: Universidad de Costa Rica, Escuela de Nutrición. Documento impreso.

Campaña

Páez, P.; Rodríguez, S (2000). Asesoría para la comercialización del frijol deshidratado. San José, Costa Rica: Universidad de Costa Rica, Escuela de Nutrición. Documento Impreso.

Dumani, M; Rodríguez, S. 2000. De todo con frijoles. Universidad de Costa Rica, Escuela de Nutrición/ CITAPrograma Bean Cowpea CRSP-AID. San José, Costa Rica: Diseño y arte Amón. p.35.

Rodríguez, L.; Rodríguez, S. 2004. Proceso metodológico para la planificación y ejecución de una Campaña educativa para incrementar el consumo de frijoles. Agronomía Mesoamericana 15(3): 327-341.

Dumani, M,; López, E. 2004. Monitoreo de los materiales escritos y de los puestos de información de una Campaña educativa para aumentar el consumo de frijoles. Agronomía Mesoamericana 15(3): 343-355.

Rodríguez, L; Fernández, X. 2003. Los frijoles (Phaseolus vulgaris): Su aporte a la dieta del costarricense. Acta Médica Costarricense. 45(3): 120-125.

5) Evaluación Rodríguez, L.; Rodríguez, S. 2001. Informe agosto 2001 del proyecto "Campaña educativa para incrementar el consumo de frijoles”. San José, Costa Rica: Universidad de Costa Rica, Escuela de Nutrición. Documento impreso.

Rodríguez, L; Dumani, M; Páez, P e Ivankovich, C. 2002. Informe de julio del 2002 del proyecto "Campaña educativa para incrementar el consumo de frijoles". San José, Costa Rica: Universidad de Costa Rica, Escuela de Nutrición. Documento impreso.

Rodríguez, L; Páez, P. 2004. Incremento del consumo de frijoles en una población urbana por medio de una Campaña educativa. Agronomía Mesoamericana 15(3): 357-363.

Rodríguez, L. 2004. Efectos de una Campaña educativa sobre frijoles en un grupo de escolares. Agronomía Mesoamericana 15(3): 379-392.

Dumani, M.; Páez, P. 2004. Efectos de una Campaña educativa sobre frijoles en un grupo de mujeres. Agronomía Mesoamericana 15(3): 365-378. 
Table 1. Phases of the process and publications. Educational Campaign to Increase Bean Consumption. Sabanilla de Montes de Oca, Costa Rica 1999-2004.

Phases of the Process

\section{Publicactions}

1) Initial Campos E, Fernández A, Sánchez I, Sancho T.; Villalobos C. 1999. Diagnóstico para el diseño de una Campaña assessment educativa tendiente a incrementar el consumo de frijoles en una comunidad urbana de clase media de Costa Rica. Seminario de Licenciatura. San José, Costa Rica: Universidad de Costa Rica.. 153 p.

Rodríguez, L.; Dumani, M. 2000 a. Diagnóstico para una Campaña educativa para la promoción del consumo de frijoles. In: Libro de Resúmenes de Trabajos Libres del XII Congreso Latinoamericano de Nutrición; SLAN 2000. Buenos Aires, Argentina: Secretaría Científica CESNI.

Rodríguez, L; Dumani M. 2000 b. Campaña educativa con respecto al consumo de frijoles. In: Memorias del IV Taller Anual de Resultados de Investigación y Transferencia de Tecnología PITTA-Frijol. Ed. por Revista Agro nomía Mesoamericana. San José, Costa Rica: Profrijol.

Rodríguez, L; Rodríguez, S. 2003. Consumo de frijoles y atención en salud de familias de una comunidad urbana de Costa Rica .Revista Costarricense de Salud Pública. Año 12, No. 23: 47-51.

Murillo, A.; Rodríguez, S. 2004 a. Conocimientos, actitudes y prácticas de madres de escolares con respecto a frijoles. Agronomía Mesoamericana 15(3): 277-289.

Murillo, A.; Rodríguez, S. 2004 b. Frijoles: prácticas factibles de aplicar por madres de niños escolares urbanos. Agronomía Mesoamericana 15(3): 301-313.

Dumani, M.; Rodríguez, S. 2004. Proceso de determinación de prácticas nutricionales recomendables con respecto a frijoles. Revista Costarricense de Salud Pública. Año 13 No. 24: 32-38.

Rodríguez, S; Murillo, A. 2004. Conocimientos, actitudes y prácticas de escolares con respecto a frijoles. Agronomía Mesoamericana 15(3): 291-300.

2) Message Martínez, T; Murillo, A; Rodríguez, S.; Páez, P. 2000. Elaboración de los contenidos de los mensajes de una Camdefinition paña educativa para aumentar el consumo de frijoles en una comunidad urbana de clase media. Seminario de Licenciatura. San José, Costa Rica: Universidad de Costa Rica.. 103 p.

Páez y Rodríguez. 2004. Plan de comunicación: un buen instrumento para que su campaña tenga éxito. Agronomía Mesoamericana 15(3): 315-326.

3) Campaign's Rodríguez, L.; Rodríguez, S. 2000. Informe 2000 del proyecto "Campaña educativa para incrementar el consumo planning and

4) Campaign's implementation Páez, P.; Rodríguez, S (2000). Asesoría para la comercialización del frijol deshidratado. San José, Costa Rica: Universidad de Costa Rica, Escuela de Nutrición. Documento Impreso.

Dumani, M; Rodríguez, S. 2000. De todo con frijoles. Universidad de Costa Rica, Escuela de Nutrición/ CITAPrograma Bean Cowpea CRSP-AID. San José, Costa Rica: Diseño y arte Amón. p.35.

Rodríguez, L.; Rodríguez, S. 2004. Proceso metodológico para la planificación y ejecución de una Campaña educativa para incrementar el consumo de frijoles. Agronomía Mesoamericana 15(3): 327-341.

Dumani, M,; López, E. 2004. Monitoreo de los materiales escritos y de los puestos de información de una Campaña educativa para aumentar el consumo de frijoles. Agronomía Mesoamericana 15(3): 343-355.

Rodríguez, L; Fernández, X. 2003. Los frijoles (Phaseolus vulgaris): Su aporte a la dieta del costarricense. Acta Médica Costarricense. 45(3): 120-125.

5) Final Rodríguez, L.; Rodríguez, S. 2001. Informe agosto 2001 del proyecto "Campaña educativa para incrementar el evaluation consumo de frijoles”. San José, Costa Rica: Universidad de Costa Rica, Escuela de Nutrición. Documento impreso.

Rodríguez, L; Dumani, M; Páez, P e Ivankovich, C. 2002. Informe de julio del 2002 del proyecto "Campaña educativa para incrementar el consumo de frijoles". San José, Costa Rica: Universidad de Costa Rica, Escuela de Nutrición. Documento impreso.

Rodríguez, L; Páez, P. 2004. Incremento del consumo de frijoles en una población urbana por medio de una Campaña educativa. Agronomía Mesoamericana 15(3): 357-363.

Rodríguez, L. 2004. Efectos de una Campaña educativa sobre frijoles en un grupo de escolares. Agronomía Mesoamericana 15(3): 379-392.

Dumani, M.; Páez, P. 2004. Efectos de una Campaña educativa sobre frijoles en un grupo de mujeres. Agronomía Mesoamericana 15(3): 365-378. 
vos. Los artículos de Dumani y Páez (2004) y Rodríguez (2004); presentan cuadros que sumarizan esa información.

La entrevista grupal con el equipo de trabajo a cargo del proyecto, reveló que el proceso desarrollado fue valorado por los involucrados como una excelente experiencia. Algunas de las opiniones que externaron al respecto fueron: "ha constituido un gran aprendizaje"; "la Campaña es pionera en muchos sentidos", "es un abordaje útil para otros alimentos", "puede contribuir a mejorar el estado nutricional de la población", "parte de la realidad y no sólo de criterios puramente técnicos"; "plantea una estrategia educativa focalizada" y "utiliza una combinación de medios y canales que permiten confirmar la información a la población".

El grupo también percibió que la información brindada por medio de la Universidad de Costa Rica, tenía un alto grado de confiabilidad para la población. Esto fue positivo para el proyecto, ya que la "credibilidad percibida con respecto a la fuente de información puede afectar la respuesta de la población al mensaje" (Gillespei y Yarbrough 1984).

Las opiniones y el interés demostrado por la Empresa Pedro Oller sobre el proyecto (Oller 2001) ${ }^{6}$ fueron también muy positivas y reflejan la factibilidad de establecer alianzas estratégicas con la industria de alimentos.

En conclusión, la metodología utilizada constituye una buena alternativa para lograr que la educación nutricional tenga efectos que incidan no sólo en los conocimientos, sino en las actitudes y las prácticas.

El proyecto desarrolló todas las etapas del proceso y cumplió con los objetivos propuestos. Además permitió crear nexos y proyectarse en el nivel local y nacional. Al mismo tiempo, el planificar y desarrollar una Campaña con las características descritas, permitió la obtención de pautas para un abordaje de la educación nutricional focalizada alrededor de un alimento específico con muchos actores y canales, y sustentada en la realidad sociocultural de la población.

\footnotetext{
6 Oller, J. 2001. Coordinación entre la empresa y el proyecto "Campaña educativa para incrementar el consumo de frijoles". Gerente División Industrial Pedro Oller S.A. Comunicación personal.
}

articles by Dumani and Páez (2004) and Rodríguez (2004), present tables summarizing this information.

The group interview with the team in charge of the Project, revealed that the effort made was judged by participants as an excellent experience. Some of their opinions about the Project were: "it has been a great learning experience"; "it is a pioneer Campaign in many senses"; "it is a useful strategy to be used with other foods"; "it can contribute to improve the population's nutritional condition"; "it was based on reality and not only on technical criteria"; "it proposes a focalized educational strategy"; and "it uses a combination of means and communication channels to reinforce the information delivered to the population".

The work team also perceived that people really trusted the information provided to them through the University of Costa Rica. This was positive for the Project, and confirms Gillespei and Yarbrough (1984) statement that "credibility in the source of information may affect people's response to the message".

The opinions of the representative from the Pedro Oller company about the Project (Oller 2001) ${ }^{6}$, and the interest this company showed, were also very positive and they prove that establishing strategic partnerships with the food industry is actually possible.

In conclusion, the methodology used is a good alternative for nutritional education to succeed and produce an impact not only on people's knowledge, but also on their attitudes and practices.

During the Project, all the phases of the process were implemented, meeting all the proposed objectives. In addition, relationships with the community were established through the Project, and it had an impact at both local and national levels. At the same time, planning and implementing the Campaign with the characteristics described made it possible to draw up some guidelines for an approach to nutritional education focused in one single food with many actors and communication channels, and based on people's socio-cultural reality.

\footnotetext{
6 Oller, J. 2001. Coordination between the company and the Project "Educational Campaign to increase nean consumption". Pedro Oller, S.A., Industrial Department Manager. Personal interview.
} 


\section{LITERATURA CITADA}

ADRIEN, M. 1994. Social Communication in nutrition: a methodology for intevention. Rome, Italy: FAO. p. 79.

ALCALAY, R. 1983. The impact of mass communication campaigns in the health field. Social scientists medicine 17 (2): 87-94.

CAMPOS, E; FERNÁNDEZ, A; SÁNCHEZ, I; SANCHO, T.;VILLALOBOS, C. 1999. Diagnóstico para una Campaña Educativa para aumentar el consumo de frijol en una comunidad del área urbana de clase media. Seminario de Licenciatura. San José, Costa Rica: Universidad de Costa Rica. 153 p.

CHINNOCK, A.; DE BEAUSETTE, I. 1996. Propuesta metodológica para la educación nutricional. Rev Costarricense de Salud Pública 5(8): 17-22.

DEPARTMENT OF AGRICULTURE, US. 2000. Base de datos: composición de alimentos. (en línea). USA. Consultado setiembre 2000. Disponible en http:// www.nal.usda/fnic.

DUMANI, M.; PÁEZ, P. 2004. Efectos de una Campaña educativa sobre frijoles en un grupo de mujeres. Agronomía Mesoamericana 15(3): 365-378.

; LÓPEZ, E. 2004. Monitoreo de los materiales escritos y de los puestos de información de una campaña educativa para aumentar el consumo de frijoles. San José, Costa Rica. Agronomía Mesoamericana 15(3): 343-355.

; RODRÍGUEZ, S. 2004. Proceso de determinación de prácticas nutricionales recomendables con respecto a frijoles. Revista Costarricense de Salud Pública. Año 13 No 24: 32-38.

; RODRÍGUEZ S. 2000. De Todo con Frijoles. San José, Costa Rica: Universidad de Costa Rica, Escuela de Nutrición/CITA-Programa Bean Cowpea CRSP-AID. p. 35.

EARL, R.; BORRA, S T. 2000. Guidelines for dietary planning. In: Krause's Food, Nutrition and Diet Therapy. $10^{\text {th }}$ Ed. USA: W.B. Saunders Company. pp. 363-385.

FAO. 1994. Guía para proyectos participativos en nutrición. Rome, Italy: FAO. p.80.

GILLESPEI, A; YARBROUGH, P. 1984. A conceptual Model for Communicating Nutrition. J Nut Ed 16 (4): 168- 172.

INCAP/ICNND/ MINISTERIO DE SALUBRIDAD PÚBLICA DE COSTA RICA, 1969. Evaluación Nutricional de la Población de Centroamérica y Panamá: Costa Rica. Publicación INCAP-V-28. Guatemala, Guatemala: INCAP. 113 p.

\section{REFERENCES}

ADRIEN, M. 1994. Social Communication in nutrition: a methodology for intevention. Rome, Italy: FAO. p. 79.

ALCALAY, R. 1983. The impact of mass communication campaigns in the health field. Social scientists medicine 17 (2): 87-94.

CAMPOS, E; FERNÁNDEZ, A; SÁNCHEZ, I; SANCHO, T.;VILLALOBOS, C. 1999. Diagnóstico para una Campaña Educativa para aumentar el consumo de frijol en una comunidad del área urbana de clase media. Seminario de Licenciatura. San José, Costa Rica: Universidad de Costa Rica. 153 p.

CHINNOCK, A.; DE BEAUSETTE, I. 1996. Propuesta metodológica para la educación nutricional. Rev Costarricense de Salud Pública 5(8): 17-22.

DEPARTMENT OF AGRICULTURE, US. 2000. Base de datos: composición de alimentos. (en línea). USA. Consultado setiembre 2000. Disponible en http:// www.nal.usda/fnic.

DUMANI, M.; PÁEZ, P. 2004. Efectos de una Campaña educativa sobre frijoles en un grupo de mujeres. Agronomía Mesoamericana 15(3): 365-378.

; LÓPEZ, E. 2004. Monitoreo de los materiales escritos y de los puestos de información de una campaña educativa para aumentar el consumo de frijoles. San José, Costa Rica. Agronomía Mesoamericana 15(3): 343-355.

; RODRÍGUEZ, S. 2004. Proceso de determinación de prácticas nutricionales recomendables con respecto a frijoles. Revista Costarricense de Salud Pública. Año 13 No 24: 32-38.

; RODRÍGUEZ S. 2000. De Todo con Frijoles. San José, Costa Rica: Universidad de Costa Rica, Escuela de Nutrición/CITA-Programa Bean Cowpea CRSP-AID. p. 35.

EARL, R.; BORRA, S T. 2000. Guidelines for dietary planning. In: Krause's Food, Nutrition and Diet Therapy. $10^{\text {th }}$ Ed. USA: W.B. Saunders Company. pp. 363-385.

FAO. 1994. Guía para proyectos participativos en nutrición. Rome, Italy: FAO. p.80.

GILLESPEI, A; YARBROUGH, P. 1984. A conceptual Model for Communicating Nutrition. J Nut Ed 16 (4): 168- 172 .

INCAP/ICNND/ MINISTERIO DE SALUBRIDAD PÚBLICA DE COSTA RICA, 1969. Evaluación Nutricional de la Población de Centroamérica y Panamá: Costa Rica. Publicación INCAP-V-28. Guatemala, Guatemala: INCAP. 113 p. 
MARTÍNEZ, T; MURILLO, A; RODRÍGUEZ, S.; PÁEZ, P. 2000. Elaboración de los contenidos de los mensajes de una Campaña Educativa para aumentar el consumo de frijoles en una comunidad urbana de clase media. Seminario de Licenciatura. San José, Costa Rica. Universidad de Costa Rica. 103 p.

MINISTERIO DE SALUD. 1996. Encuesta nacional de nutrición. Fascículo 3: consumo aparente. San José, Costa Rica. Ministerio de Salud. p. 45.

2001. Guías alimentarias para la educación nutricional en Costa Rica. 3 $3^{\text {era }}$. Ed. San José, Costa Rica: Ministerio de Salud. p. 90.

MORÓN, C.; CALDERÓN,T. 1999. La elaboración de guías alimentarias basadas en alimentos de América Latina. Revista Alimentación, Nutrición y Agricultura. No. 24 Roma, Italia: Dirección editorial de la FAO. p. 27.

NAVARRO, R. 1998. Manual de técnicas de enseñanza para la educación nutricional de adultos. Memoria Práctica Dirigida de Licenciatura. San José, Costa Rica. Universidad de Costa Rica. 78 p.

PÁEZ, P; RODRÍGUEZ, L. 2004. Plan de comunicación: un buen instrumento para que su campaña tenga éxito.San José. Costa Rica. Agronomía Mesoamericana 15(3): 315-326.

PARDÍO, J; PLAZAS M. 1998. Modelos para el cambio de conducta. Cuadernos de Nutrición 21 (5): 58-64.

RODRÍGUEZ, L. 2004. Efectos de una Campaña educativa sobre frijoles en un grupo de escolares. San José, Costa Rica. Agronomía Mesoamericana 15(3): 379-392.

; PÁEZ, P. 2004. Incremento del consumo de frijoles en una población urbana por medio de una Campaña educativa. San José, Costa Rica.Agronomía Mesoamericana 15(3): 357-363.

; DUMANI, M. 2000 a. Diagnóstico para una Campaña educativa para la promoción del consumo de frijoles. In: Libro: de Resúmenes de Trabajos Libres del XII Congreso Latinoamericano de Nutrición; SLAN 2000. Buenos Aires, Argentina: Centro de estudios sobre Nutrición Infantil (CESNI). p. 375.

; DUMANI, M. 2000 b. Campaña educativa con respecto al consumo de frijoles. In: Memorias del IV Taller Anual de Resultados de Investigación y Transferencia de Tecnología Pitta-Frijol. Ed. por Revista Agronomía Mesoamericana. San José, Costa Rica: Profrijol. p. 35-41.

; FERNÁNDEZ, X. 2003. Los frijoles (Phaseolus vulgaris): Su aporte a la dieta del costarricense. Acta Médica Costarricense. 45(3): 120-125.

; RODRÍGUEZ, S. 2003. Consumo de frijoles y atención en salud de familias de una comunidad urbana
MARTÍNEZ, T; MURILLO, A; RODRÍGUEZ, S.; PÁEZ, P. 2000. Elaboración de los contenidos de los mensajes de una Campaña Educativa para aumentar el consumo de frijoles en una comunidad urbana de clase media. Seminario de Licenciatura. San José, Costa Rica. Universidad de Costa Rica. 103 p.

MINISTERIO DE SALUD. 1996. Encuesta nacional de nutrición: Fascículo 3: consumo aparente. San José, Costa Rica. Ministerio de Salud. p. 45.

2001. Guías alimentarias para la educación nutricional en Costa Rica. 3 $3^{\text {era }}$. Ed. San José, Costa Rica: Ministerio de Salud. p. 90.

MORÓN, C.; CALDERÓN,T. 1999. La elaboración de guías alimentarias basadas en alimentos de América Latina. Revista Alimentación, Nutrición y Agricultura. No. 24 Roma, Italia: Dirección editorial de la FAO. p. 27.

NAVARRO, R. 1998. Manual de técnicas de enseñanza para la educación nutricional de adultos. Memoria Práctica Dirigida de Licenciatura. San José, Costa Rica. Universidad de Costa Rica. 78 p.

PÁEZ, P; RODRÍGUEZ, L. 2004. Plan de comunicación: un buen instrumento para que su campaña tenga éxito.San José. Costa Rica. Agronomía Mesoamericana 15(3): 315-326.

PARDÍO, J; PLAZAS M. 1998. Modelos para el cambio de conducta. Cuadernos de Nutrición 21 (5): 58-64.

RODRÍGUEZ, L. 2004. Efectos de una Campaña educativa sobre frijoles en un grupo de escolares. San José, Costa Rica. Agronomía Mesoamericana 15(3): 379-392.

; PÁEZ, P. 2004. Incremento del consumo de frijoles en una población urbana por medio de una Campaña educativa. San José, Costa Rica.Agronomía Mesoamericana 15(3): 357-363.

; DUMANI, M. 2000 a. Diagnóstico para una Campaña educativa para la promoción del consumo de frijoles. In: Libro: de Resúmenes de Trabajos Libres del XII Congreso Latinoamericano de Nutrición; SLAN 2000. Buenos Aires, Argentina: Centro de estudios sobre Nutrición Infantil (CESNI). p. 375.

; DUMANI, M. 2000 b. Campaña educativa con respecto al consumo de frijoles. In: Memorias del IV Taller Anual de Resultados de Investigación y Transferencia de Tecnología Pitta-Frijol. Ed. por Revista Agronomía Mesoamericana. San José, Costa Rica: Profrijol. p. 35-41.

; FERNÁNDEZ, X. 2003. Los frijoles (Phaseolus vulgaris): Su aporte a la dieta del costarricense. Acta Médica Costarricense. 45(3): 120-125.

; RODRÍGUEZ, S. 2003. Consumo de frijoles y atención en salud de familias de una comunidad urbana 
de Costa Rica. Revista Costarricense de Salud Pública Año 12, No. 23: 47-51.

RODRÍGUEZ, L.; RODRÍGUEZ, S. 2004. Proceso metodológico para la planificación y ejecución de una Campaña educativa para incrementar el consumo de frijoles. Agronomía Mesoamericana 15(3): 327-342.

SÁENZ, L. 1995. Evolution of epidemiological profile. In: Muñoz, C; Scrimshaw, N. The nutrition and health transition of democratic Costa Rica. Boston, MA, USA: International Fundation for Developing Countries. p. 119-143.

SÁENZ, S. 1995. Estudio etnográfico sobre el manejo de infecciones respiratorias agudas en Metapán: Capítulo 6, intervención educativa. El Salvador. Guatemala: Publicación INCAP DOE/IP/084. p. 39-50.

SEDÓ, P. 2001. Alimentos funcionales: análisis general acerca de las características químico-nutricionales, desarrollo industrial y legislación alimentaria. Rev. Costarricense de Salud Pública Año 10, No. 18 y 19: 34-39.

2002. El mercado de los alimentos funcionales y los nuevos retos para la educación alimentaria-nutricional. Rev Costarricense de Salud Pública Año 11, No. 20: 18-25.

SIZER, F; WHITNEY, E. 1997. Nutrition: Concepts and Controversies. $7^{\text {th }}$ Ed. USA, West/Wadsworth: International Thompson Publishing Company. p. 626. de Costa Rica. Revista Costarricense de Salud Pública. Año 12, No. 23: 47-51.

RODRÍGUEZ, L.; RODRÍGUEZ, S. 2004. Proceso metodológico para la planificación y ejecución de una Campaña educativa para incrementar el consumo de frijoles. Agronomía Mesoamericana 15(3): 327-342.

SÁENZ, L. 1995. Evolution of epidemiological profile. In: Muñoz, C; Scrimshaw, N. The nutrition and health transition of democratic Costa Rica. Boston, MA, USA: International Fundation for Developing Countries. p. 119-143.

SÁENZ, S. 1995. Estudio etnográfico sobre el manejo de infecciones respiratorias agudas en Metapán: Capítulo 6, intervención educativa. El Salvador. Guatemala: Publicación INCAP DOE/IP/084. p. 39-50.

SEDÓ, P. 2001. Alimentos funcionales: análisis general acerca de las características químico-nutricionales, desarrollo industrial y legislación alimentaria. Rev. Costarricense de Salud Pública Año 10, No. 18 y 19: 34-39.

2002. El mercado de los alimentos funcionales y los nuevos retos para la educación alimentaria-nutricional. Rev Costarricense de Salud Pública Año 11, No. 20: 18-25.

SIZER, F; WHITNEY, E. 1997. Nutrition: Concepts and Controversies. $7^{\text {th }}$ Ed. USA, West/Wadsworth: International Thompson Publishing Company. p. 626. 